\title{
Persistence of dryland pasture species in mixed swards in Canterbury
}

\author{
T.J. FRASER
}

AgResearch, PO Box 60, Lincoln

\section{Abstract}

Changes in dryland pasture composition were monitored over 5 years in pastures that were managed under a normal sheep farm management system. Grass grub population built up with time and appeared to be the main reason for plant loss and the resultant changes in pasture composition. Grass grub densities in ryegrass mixtures increased to a high level $\left(220 / \mathrm{m}^{2}\right)$ by year three, with subsequent loss of ryegrass plants. Grub densities increased more slowly in cocksfoot-, tall fescueand phalaris-based pastures, with no apparent loss of plants. Cocksfoot dominated pasture composition by year three, even when sown at only $25 \%$ of total seed mix. Phalaris did not increase its contribution and at no stage made a significant contribution to production when sown in mixtures with other grasses. As grass grub numbers declined there appeared to be some regeneration of the ryegrass component. The more persistent cocksfoot and tall fescue pastures increased their herbage yield advantage over ryegrass pastures with time. Autumn animal performance was directly related to the amount of green herbage on offer.

Keywords: Costelytra zealandica, Dactylis glomerata,dryland pastures, Festuca arundinacea, Lolium perenne, Phalaris aquatica, pasture composition

\section{Introduction}

There has been a marked increase in the use of alternative species for summer dry regions over the past decade (Milne \& Fraser 1990; Macfarlane 1990; Moloney 1993) . However, research has concentrated on pure swards or simple one grass one legume mixtures. Furthermore, most trials have examined performance only in the short term and under ideal management situations, where pastures have been protected from grass grub (Costefytra zealandica) damage with the use of insecticide. This is an important factor when looking at the effect of grass grub on pasture composition and persistence.

This paper follows the change in grass grub population, pasture composition, herbage production and animal performance over $\mathbf{5}$ years of 8 different pasture mixtures.

\section{M ethods}

The trial, of 2 replications and 8 grass mixtures in various combinations of high endophyte Grasslands Nui perennial ryegrass (Lolium perenne), Grasslands Wana cocksfoot (Dactylis glomerata), Grasslands Roa tall fescue (Festuca arundinacea), and Grasslands Maru phalaris (Phalaris aquatica) sown with Grasslands Tahora white clover (Trifolium repens), was established in autumn 1989 (Table 1). These pastures were sown into a Templeton stony silt loam at Lincoln. The area had been summer fallowed and irrigation was available to assist with establishment and was used in the first autumn only. Soil quick test at sowing was pH 5.7, phosphorus 14 and sulphur 7. Maintenance fertiliser of $150 \mathrm{~kg} / \mathrm{ha}$ of superphosphate was applied in spring. Treatments were replicated twice and individually fenced into paddocks of 0.1 ha that enabled monitoring of some animal performance measurements as well as herbage production and pasture composition.

Table-1-Seeding-rates-(kg/ha)af grass component.

\begin{tabular}{|c|c|c|c|c|c|}
\hline Treatment & Phalaris & Ryegrass & Cocksfoot & Tall & fescue \\
\hline 1 & 6 & & & & \\
\hline 2 & 3 & 10 & & & \\
\hline 3 & 3 & & 3 & & \\
\hline 4 & 3 & & & & 10 \\
\hline 5 & 3 & 7 & & & 7 \\
\hline 6 & 3 & 7 & 2 & & \\
\hline 7 & 3 & & 2 & & 7 \\
\hline 8 & 3 & 7 & 2 & & 7 \\
\hline
\end{tabular}

Pasture management followed as closely as possible to that practised by most dryland sheep farmers of set stocking from lambing to weaning, short rotation (21 to 28 days) over summer, long rotation (35 to 42 days) over autumn, with one hard winter graze. At all grazings pastures were hard grazed to a residual of 500 to 700 $\mathrm{kg} / \mathrm{ha}$.

Herbage production was measured by cutting eight $0.25 \mathrm{~m}^{2}$ quadrats per plot prior to grazing with subsamples taken for botanical composition. Grass grub populations were assessed in March from years 2 to 5 
by taking 20 random spade $(200 \times 200 \mathrm{~mm}$ to a depth of $150 \mathrm{~mm}$ ) samples per plot. Animal liveweight performance was measured over the late spring and summer of year two. Sheep were fasted for 24 hours, weighed, randomly allocated to treatments for a period of 42 days, then fasted and weighed off. Plots were stocked to give similar total herbage allowances per animal.

\section{R esults and discussion}

Grass grub numbers peaked by year two (Table 2) and were significantly higher in ryegrass-based pastures than in other grass mixtures. This coincided with a loss of ryegrass plants (Table 3) and as pastures had been under no drought stress and the use of an endophyte ryegrass protected the plants from stem weevil attack, it could be concluded that grass grub was the cause of plant loss. Cocksfoot and tall fescue-based pastures did not decline in density over the period of the trial (Table 3) even in the presence of moderate numbers of grass grubs, supporting farmer evidence that these species are tolerant to grass, grub attack. Grass grub numbers reached medium numbers in treatment one, where phalaris was the only sown grass, by year 3 . This suggests that although phalaris is recognised as being resistant to grass grub it does not suppress grass grub numbers, particularly in the presence of white clover and weeds, which made up a significant component in this treatment from year -3 (Table 3).

These results support earlier work in New Zealand. Grass grub numbers are normally low in new pastures established by conventional cultivation and increase predictably (East \& Kain 1982) to reach a peak in 3-5 years (Jackson 1990). then collapsing due to bacterial invasion and starvation (Kain 1975), and other biological factors (Jackson 1990).

Wana cocksfoot tended to dominate pasture composition by year 3 even when sown at only $25 \%$ of total seed mix. This observations supports those made by other researchers (Korte et al. 1992; Smith et $a l$. 1993; Milne \& Moloney 1993; Fraser \& Hewson 1994). While the dominance of Wana cocksfoot has been considered as a negative by some researchers and farmers (Moloney 1993), it is one of the only pasture cultivars
Table 2 Grass grab numbers $/ \mathrm{m}^{2}$.

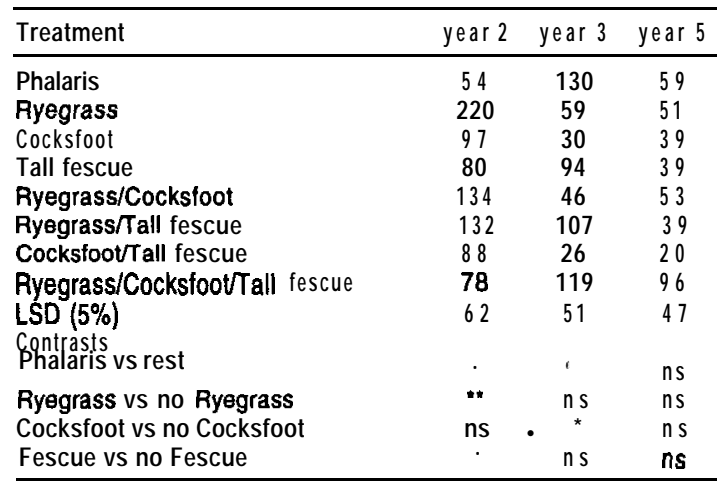

$\mathrm{ns}=$ not significant

. $=(P<0.05)$

" $=(P<0.01)$

Table 3 Autumn pasture composition $\%$ of total.

\begin{tabular}{|c|c|c|c|c|c|c|c|c|}
\hline Treatment & Year & phal & rye & $\cos x$ & fesc & $w / c$ & w e e & yield' \\
\hline control & $\begin{array}{l}2 \\
3 \\
5\end{array}$ & $\begin{array}{l}65 \\
64 \\
56\end{array}$ & & & & $\begin{array}{c}23 \\
8 \\
21\end{array}$ & $\begin{array}{l}12 \\
28 \\
23\end{array}$ & $\begin{array}{l}100(2156) \\
100(1265) \\
100(2410)\end{array}$ \\
\hline ryegrass & $\begin{array}{l}3 \\
5\end{array}$ & $\begin{array}{l}19 \\
48 \\
39\end{array}$ & $\begin{array}{l}58 \\
24 \\
28\end{array}$ & & & $\begin{array}{c}12 \\
4 \\
19\end{array}$ & $\begin{array}{l}11 \\
23 \\
15\end{array}$ & $\begin{array}{l}99 \\
75 \\
97\end{array}$ \\
\hline cocksfoot & $\begin{array}{l}2 \\
3 \\
5\end{array}$ & $\begin{array}{l}13 \\
6 \\
3\end{array}$ & & $\begin{array}{l}69 \\
83 \\
29\end{array}$ & & $\begin{array}{l}15 \\
28\end{array}$ & $\begin{array}{l}3 \\
8 \\
0\end{array}$ & $\begin{array}{l}110 \\
105 \\
102\end{array}$ \\
\hline fescue & $\begin{array}{l}2 \\
3 \\
5\end{array}$ & $\begin{array}{l}16 \\
22 \\
23\end{array}$ & & & $\begin{array}{l}52 \\
63 \\
43\end{array}$ & $\begin{array}{l}26 \\
5 \\
20\end{array}$ & $\begin{array}{c}6 \\
7 \\
14\end{array}$ & $\begin{array}{l}118 \\
97 \\
108\end{array}$ \\
\hline$r y e / c o x$ & $\begin{array}{l}2 \\
3 \\
5\end{array}$ & $\begin{array}{c}10 \\
9 \\
2\end{array}$ & $\begin{array}{c}23 \\
7 \\
5\end{array}$ & $\begin{array}{l}39 \\
69 \\
74\end{array}$ & & $\begin{array}{l}21 \\
6 \\
15\end{array}$ & $\begin{array}{l}7 \\
8 \\
3\end{array}$ & $\begin{array}{l}91 \\
95 \\
96\end{array}$ \\
\hline rye/fes & $\begin{array}{l}2 \\
3 \\
5\end{array}$ & $\begin{array}{l}15 \\
20 \\
12\end{array}$ & $\begin{array}{l}38 \\
10 \\
15\end{array}$ & & $\begin{array}{l}23 \\
58 \\
45\end{array}$ & $\begin{array}{l}26 \\
4 \\
18\end{array}$ & $\begin{array}{c}8 \\
7 \\
11\end{array}$ & $\begin{array}{l}119 \\
90 \\
107\end{array}$ \\
\hline cox/fes & $\begin{array}{l}2 \\
3 \\
5\end{array}$ & $\begin{array}{l}11 \\
8 \\
3\end{array}$ & & $\begin{array}{l}47 \\
66 \\
70\end{array}$ & $\begin{array}{l}15 \\
16 \\
13\end{array}$ & $\begin{array}{c}15 \\
6 \\
14\end{array}$ & $\begin{array}{l}12 \\
5 \\
0\end{array}$ & $\begin{array}{c}114 \\
98 \\
114\end{array}$ \\
\hline rye/cox/les & $\begin{array}{l}2 \\
3 \\
5\end{array}$ & $\begin{array}{l}11 \\
6 \\
2\end{array}$ & $\begin{array}{c}18 \\
7 \\
4\end{array}$ & $\begin{array}{l}39 \\
60 \\
65\end{array}$ & $\begin{array}{l}11 \\
14 \\
10\end{array}$ & $\begin{array}{c}15 \\
4 \\
19\end{array}$ & $\begin{array}{l}6 \\
8 \\
0\end{array}$ & $\begin{array}{r}101 \\
86 \\
106\end{array}$ \\
\hline
\end{tabular}

1 total autumn herbage yield, control as 100. (actual kglha for control)

that will persist and produce acceptable herbage production in low to medium fertility, summer dry areas.

Maru phalaris made no significant contribution to autumn production when sown in mixtures with other drought-tolerant grasses. Phalaris did increase as a percentage of sown grasses when sown with ryegrass, but this was a reflection of the loss of ryegrass rather than an increase in phalaris production. There was a 
significant increase in weed grasses in both this treatment and where phalaris was sown as the only grass (control). It was observed that phalaris tended to dominate and made a greater contribution to pasture production around sheep camps, which are generally areas of higher fertility. This is consistent with some farmer comment and requires further research.

The slower establishing Roa tall fescue when sown with cocksfoot made up no more than $15 \%$ of pasture composition in this mixture. The availability of the fasterestablishing Grasslands Advance tall fescue (Fraser \& Lyons 1994) may overcome this problem. The loss of the ryegrass component when sown with tall fescue ( $38 \%$ in year 2, compared with $15 \%$ in year 5) was an unexpected and may be a result of grass grub damage.

White clover production was adequate (15 to 20\%) except in year 3, when autumn rainfall was less than half of long term mean, and in cocksfoot pastures. The suppression of white clover in Wana cocksfootdominant pastures is similar to that reported in other trials (Moloney 1993) and farmer observation.

By the fifth year grass grub numbers had declined and there was evidence of regeneration of the ryegrass component in pastures where cocksfoot was not in the seed mixture. It is interesting to note that many dryland pastures sown in predominantly ryegrass-based seed mixtures are ploughed up by year 4 because grass grub have destroyed the pasture. However, this cultivation kills most of the natural biological controls, thus exposing new sowings to renewed grass grub attack (Jackson 1990). There are two management options available to overcome this problem. Firstly, the present results indicate that the pasture will return to full production given time, so one management option is to accept the loss of production as the pasture goes through this phase. Alternatively, if renewal of the pasture is decided on, direct drilling using the spray fallow technique (Fraser \& Hewson 1994) should be followed.

Table 4 Animal growth rates in autumn.

\begin{tabular}{|c|c|c|c|c|c|c|}
\hline \multirow{2}{*}{$\begin{array}{l}\text { Treatment } \\
\text { Phalaris }\end{array}$} & \% green' & $\begin{array}{r}\text { Year } \\
\mathrm{SR}^{2}\end{array}$ & $\begin{array}{c}\text { growthl } \\
\text { rate }^{3}\end{array}$ & $\%$ gree & $\begin{array}{l}\text { Year } 3 \\
n \text { SR }\end{array}$ & $\begin{array}{c}\text { growthl } \\
\text { rate }\end{array}$ \\
\hline & 86 & 40 & 168 & 52 & 30 & -10 \\
\hline Ryegrass & 72 & 40 & 136 & 47 & 30 & -25 \\
\hline Cocksfoot & 79 & 45 & 158 & 68 & 30 & +25 \\
\hline Fescue & 04 & 55 & 160 & 68 & 40 & +25 \\
\hline RyelCox & 69 & 40 & 134 & 71 & 30 & +43 \\
\hline RyelFes & 74 & 50 & 134 & 60 & 30 & +32 \\
\hline & 88 & 45 & 204 & 64 & 40 & +30 \\
\hline RvelCoxiFes & 82 & 45 & 215 & 63 & 40 & +35 \\
\hline
\end{tabular}

$1 \%$ of total on offer as green material

2 stocking rate for grazing period

3 sheep growth rate gmslday
Increased autumn animal performance was directly related $\left(r^{2}=0.82\right)$ to the amount of green herbage on offer (Table 4), demonstrating the importance of selecting pasture species that will persist and produce green leaf during the warm season.

\section{ACKNOWLEDGEMENTS}

Lesley Hunt for statistical analyses.

\section{REFERENCES}

East, R.; Kain, W.M. 1982. Prediction of grass grub, Costelytra zealandica (Coleoptra Scarabaeidae) populations. NZ entomologist 7: 222-227.

Fraser, T.J.; Hewson, D.C. 1994. Establishing pastures on East Coast downlands by direct drilling. Proceedings of the NZ Grassland Association 56 (this volume).

Fraser, T.J.; Lyons, T. 1994. Advance tall fescue. Proceedings of the NZ Grassland Association 56 (this volume).

Jackson, T.A. 1990. Biological control of grass grub in Canterbury. Proceedings of the NZ Grassland Association 52: 2 17-220.

Kain, W.M. 1975. Population dynamics and pest assessment studies of grass grub in the North Island of New Zealand. PhD thesis, Lincoln college, University of Canterbury.

Korte, C.J.; Smith, D.R.; Slay, M.W.A.; Gray, M.H.; Quilter, S.J. 1992. Summary report for farmers.on.a survey of East Coast drought tolerant pastures. AgResearch report.

MacFarlane, A.W. 1990. Field experience with new pasture cultivars in Canterbury. Proceedings of the New Zealand Grassland Association 52:139- 143.

Moloney, S.C. 1993. Selection, management and use of cocksfoot cultivars in North Island pastoral farming. Proceedings of the New Zealand Grassland Association 55: 119- 125.

Milne, G.D.; Fraser, T.J. 1990. Establishment of 1600 hectares in dryland species around-Oamaru/Timaru: Proceeding of the New Zealand Grassland Association 52: 133-1337.

Milne, G.D.; Moloney, SC.; Smith, D.R. 1993. Demonstration of dryland species on 90 East Coast North Island farms. Proceedings of the New Zealand Grassland Association 55: 39-44.

Smith, D.R.; Slay, M.W.A.; Gray, M.H.; Milne, G.D. 1993. On-farm establishment of drought tolerant pastures on East Coast of the North Island. Proceedings of the New Zealand Grassland Association 55: 3-38. 